\title{
2 The Paradigmatics and Conjugation of Verbs
}

\subsection{Introductory Remarks}

This chapter examines different issues connected with verb form systems, which are important also for the discussion of other verb categories (mood and voice). We will discuss the main principles of conjugation (without going into a more detailed discussion of conjugation groups), the category of tense (without going into the construction and use of tense forms), and the person category. There is no additional discussion of the Latvian system of participles here, as these are already discussed in the description of verb forms (for a discussion of Latvian participles, see, for example, Mathiassen 1997, 146-158).

Like the noun, in terms of its grammatical features, the Latvian verb presents a typical Indo-European verb system with a wide variety of forms. The Latvian verb possesses the categories of person, tense, mood, and voice; in a sentence it usually takes the function of the predicate (see, for example, Paegle 2003, 89; Kalnača 2013b, 456):

\begin{tabular}{|c|c|c|c|c|}
\hline $\begin{array}{l}\bar{A} p \text { sis } \\
\text { badger.NOM.M }\end{array}$ & $\begin{array}{l}\text { nāca } \\
\text { come.PST.3 }\end{array}$ & $\begin{array}{l}p a \\
\text { along }\end{array}$ & $\begin{array}{l}\text { slapjo } \\
\text { wast.ACC.F }\end{array}$ & $\begin{array}{l}z a \bar{a} l i . \\
\text { grass.ACC.F }\end{array}$ \\
\hline
\end{tabular}

(Sodums)

$\begin{array}{llcll}\text { Viņa } & \text { bija } & \text { ieradusies } & \text { pāri } & \text { okeānam. } \\ \text { she.Nom. } & \text { be.AUX.PST.3 } & \text { arrive.PTCP.F } & \text { across } & \text { ocean.DAT.M } \\ \text { 'She had arrived from across the ocean' } & & \end{array}$

(Skujiņš)

The verb can be the principal part of a one-part sentence, if it forms the syntactic centre in the one-part sentence:

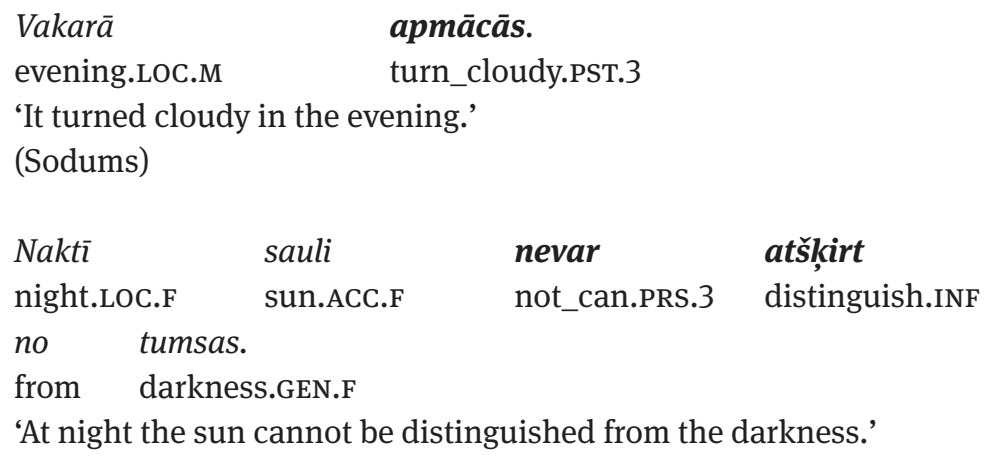


The grammatical categories of the verb - the tense, mood, voice, and person are interconnected in Latvian both paradigmatically and functionally. Thus, the categories of tense, mood, and voice form a unified gramatical form system - all moods, except the imperative mood have tense forms both in the active and passive voice. The indicative mood and the imperative mood in both active and passive voices have morphologically expressed personal forms, which are lacking in the oblique, conditional, and debitive moods (see Chapter 4). The Latvian verb form system can be interconnected also functionally, for example, indicative mood verb forms can be used in oblique, conditional, or imperative mood functions in particular contexts (see Chapter 4). The use of verb tense forms can depend on perfective/imperfective aspect, for example, when expressing a continuous action or an action which is taking place in the moment of speaking, it is usually not used in the perfective aspect (i.e., a prefixed verb form; in more detail see Section 3.3).

The verb in Latvian has several lexico-grammatical groups, which are closely connected with both lexical meaning and verb formation as well as some of the verb grammatical categories. The meaning of aspect is expressed with the semelfactive and iterative aspect lexico-grammatical groups, which are partially connected with the category of tense (see Chapter 3). The transitive and intransitive verb groups as well as causative and reflexive lexico-grammatical verb groups are connected with the category of the voice of the verb (see Section 6.3 and Chapter 7).

The transitivity and intransitivity, reflexivity, and aspect of the verb are considered lexico-grammatical verb categories in Latvian linguistics (for example, Paegle 2003, 125-130). However, it is preferable to use the lexico-grammatical group as the classification principle. This is because the transitivity, reflexivity, and aspect do not possess sufficient grammatical features in Latvian that would be expressed in the unity of the form and contents, the existence of the form constructing affixes, and the regularity of the use (for a similar approach in grammatical problem solution in lexicogrammatical group postulation in Lithuanian linguistics see, for example, Ambrazas 1996, 283-290; Ambrazas 1997, 223-237). The transitivity results from the lexical meaning of the verb, while reflexive verbs, being formally connected with reflexive endings, lack semantic and syntactic unity. Aspect is also connected with the lexical meaning of the verb, its contextual use, and its prefixal and suffixal formation.

\subsection{Conjugation}

In contrast to the relatively simple grammatical form construction of nouns (see Chapter 1), Latvian verb formation is complex and also is supplemented by different morphophonological means as well as zero morphs.

The forms of the verb are constructed (Paegle 2003, 90; Kalnača 2013a, 74-75):

1. synthetically - with the help of endings (2.3a), suffixes (2.3b), as well as prefixes (2.3c) 
(2.3)

a. personal forms

las- $u$ 'I read', las-i 'you read', las- $a$ 'he/she reads', las-ām 'we read', las-āt 'you read'

b. tense forms

sie-t 'to tie' - sie-n-u 'I tie', sie-š-u 'I will tie', sal-t 'to freeze' - sal-st-u 'I freeze', sal-š-u 'I will freeze', $k l \bar{a}-t$ 'to lay/set' - klā-j-u 'I lay/set', $k l \bar{a}-\bar{s}-u$ 'I will lay/set'

\section{participle forms}

present active aug-oš-s 'growing', past active aug-us-i 'has grown', semideclinable aug-dam-s 'growing', present passive cel̦-am-s 'raisable', past passive cel-t-s 'raised', indeclinable cel,-ot 'while raising', cel-am 'raising'

c. debitive

aug-t 'to grow' - aug-ø 'it grows' - ir jāa-aug 'it has to grow'

2. analytically - wth the help of an auxiliary verb and a declinable participle (2.4a-b), or with an auxiliary verb and a particular verb form (2.4c)

a. perfect tense forms

esmu lasījis 'I have read', biju lasījis 'I had read', būšu lasījis 'I will have read'

b. passive voice forms

tiek lasìts 'is read', tika lasìts 'was read', tiks lasits 'will be read'

c. debitive mood

ir jālasa 'has to be read', bija jālasa 'had to be read', būs jālasa 'will have to be read'

There are several suppletive verbs in Latvian:

1. būt 'to be' which has the present tense 1st and 2nd person forms esmu 'I am', esi 'you (SG) are', esam 'we are', esat 'you (PL) are' and the 3rd person form ir 'he/she is, they are';

2. iet 'to go' with the past tense forms gāju 'I went', gāji 'you went', gāja 'he/she went', gājām 'we went', gājāt 'you went', gāja 'they went' 
The construction of the grammatical forms of the verb (these are typically synthetic and formed through affixation) can usually be accompanied by a sound shift, which is customarily connected with the construction of the present tense, more seldomly the past tense or the imperative (see more about historical sound shifts in Auzina 2013, 89-95, and Kalnača 2004), for example:

1. apophony in the construction of the present indefinite and past indefinite

present

vilkt 'to wear': velku 'I wear', pirkt 'to buy' : pērku 'I buy', migt 'to fall asleep': miegu 'I fall asleep', stigt 'to sink' : stiegu 'I sink'

past

$d z e r t$ 'to drink' : $d z \bar{e} r u$ 'I drank', raut 'to tear' : rāvu 'I tore', žaut 'to hang out': $\check{z} \bar{a} v u$ 'I hung out'

2. palatalisation in the construction of the present indefinite forms

(2.6)

Infinitive
celt
plēst
griezt
pūst
grūst
braukt
lūgt

Present Indefinite
ceḷu
plēšu
griežu
pūšu
grūžu
braucu
lūdzu

$$
\begin{aligned}
& \text { 'to build - I build' } \\
& \text { 'to tear - I tear' } \\
& \text { 'to cut - I cut' } \\
& \text { 'to blow - I blow' } \\
& \text { 'to push - I push' } \\
& \text { 'to drive - I drive' } \\
& \text { 'to beg - I beg' }
\end{aligned}
$$

3. fronting (of velar consonants) determined by the following front vowels $i, \bar{\imath}, e, \bar{e}$, $i e, e i$

a. Indicative 2SG

1st person nāku, augu 'I come, I grow'

2nd person nāc, audz 'you come, you grow'

3rd person nāk, aug 'he/she comes, he/she grows'

b. Imperative 2SG

$n \bar{a} c$ !, audz! 'come! grow!'

\section{c. Imperative 2PL}

nāciet!, audziet! 'come!, grow!' 
4. deletion of the stem final $t, d, s, z$ determined by the suffix initial $s$ in the form of the present indefinite

$$
\begin{aligned}
& \text { kals-t : kal-st-ø (<*kaltst) 'to dry - it dries' } \\
& \text { plūs-t : plū-st-ø (<*plūdst) 'to flow - it flows' } \\
& \text { aus- } t \text { : au-st- } \varnothing \text { (<*ausst) 'to dawn - it dawns' } \\
& \text { lūz-t : lū-st-ø (<*lūzst) 'to break - it breaks' }
\end{aligned}
$$

5. vowel change determined by the following consonant $n$ in the forms of the present indefinite

$$
\begin{aligned}
& \text { krist : krìtu (<*krintu) 'to fall - I fall' } \\
& \text { just : jūtu (<*juntu) 'to feel - I feel' } \\
& \text { rakt : roku (<*ranku) 'to dig - I dig' }
\end{aligned}
$$

\begin{tabular}{|c|c|c|c|}
\hline Infinitive & Present 1SG & Past 1SG & Future 1SG \\
\hline sie-t 'to tie' & sien-u'I tie’ & sēj-u'I tied’ & sieš-u ‘I will tie’ \\
\hline \multirow{2}{*}{ domā-t 'to think' } & domāj-u & domāj-u & domāš-u \\
\hline & ‘I think’ & 'I thought' & 'I will think’ \\
\hline cel-t 'to raise' & cel!-u ‘I raise’ & cēl-u 'I raised' & celš-u 'I will raise' \\
\hline lasī-t'to read' & las-u'I read' & lasīj-u'I read’ & lasī̌s-u 'I will read' \\
\hline
\end{tabular}

The basis of the grammatical verb forms is the stem of the infinitive (Kalnača 2013b, 458-459). All the indefinite tense forms - present, past, future - are constructed on the basis of the infinitive stem with the help of different morphonological and morphological means:

Table 2.1: Verb stems in Latvian

Latvian linguists hold different views on which of the verb stems form the basis for the construction of the indefinite tense forms. Namely, whether these forms are based only on the infinitive stem or also the stem of the present and past tense forms (see, for example, Ahero et al. 1959, 665-667; Kalme \& Smiltniece 2001, 197-198).

The view that verb forms can be deduced from some kind of abstract stem, which can be considered as the basic paradigmatic stem (in the Baltic languages it is the stem of the infinitive form; see also Paegle 2003, 98; Kalnača 2013, 458-459) agrees with general morphological theory (see, for example, Spencer 2000, 226-227; Haspelmath 2002, 130-133) and has been applied also in Lithuanian linguistics (see, for example, Paulauskienė 1994: 281). In a similar way, Fennell (1995, 80-87), when describing the Latvian verb form construction system and depicting its traditions as they have appeared in Latvian grammar books since the 17th century, mentions the infinitive as the basic form for the construction of other forms (present, past, future) 
(see also Mathiassen 1997, 84). However, Ahero et al. (1959, 583), Kalme \& Smiltniece (2001, 197-198) and Nìtina (2001, 66-67, 71) claim that indefinite tense forms are based on three stems: the infinitive stem as well as the present and past tense stems. This viewpoint agrees with the so-called Priscianic formation principles, which have been known in grammar since the sixth century CE when they were formulated by the Latin grammarian Priscian, but which have lost their popularity in more recent times (see Haspelmath 2002, 132).

In Latvian, as in Lithuanian, the infinitive is considered as the point of departure for the verb paradigm because the infinitive does not possess any of the basic categories of the verb; it does not express the person, tense, mood, or voice. Nevertheless, the majority of the basic forms of different moods as well as the participle forms are constructed from the infinitive forms.

The distinction of the three verb conjugations in Latvian are based on the properties of the present tense stem construction as opposed to the infinitive stem (i.e., the morphemic structure of the infinitive) (Paegle 2003, 104-111; see also Kalnača 2013b, 545; and short, long, and mixed conjugations by Mathiassen 1997, 84). Thus, the construction of the present tense stem serves as the basis for the distinction between the conjugations and the basis for the distinction of the simple verb conjugation groups, as different morphological and morphonological means have been systematically used in the construction of the present stem (i.e., suffixes and sound changes). Unlike with the present tense stem, the construction of the future tense stem is the same for all verbs with the exception of the verbs of the first conjugation, whose root ends with $t, d, s, z$ and whose forms of the future contain an infix -i- next to the future suffix (nes-

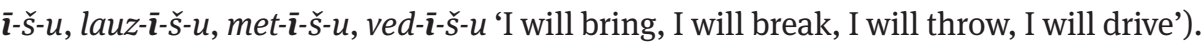
The construction of the past tense stem has also been mostly unified, therefore these tense forms cannot serve as the basis for identifying the conjugation (see more on verb conjugations in Kalnača 2013a, 2013b).

Due to the suppletive stem forms, and partially also the archaic (athematic) personal forms, the three verbs iet 'to go', dot 'to give', bùt 'to be' and their derivatives (for example, neiet 'not to go', nedot 'not to give', nebūt 'not to be', aiziet 'to walk along', iedot 'to give', pārdot 'to sell') do not fit into any of the conjugations. Therefore, these are considered to be irregular verbs from the point of view of conjugation.

\section{1st conjugation}

This conjugation contains verbs whose infinitive stem does not have a suffix: augt 'to grow', nest 'to bring', èst 'to eat', mest 'to throw', krist 'to fall', just 'to feel', snigt 'to snow', and others.

\section{2nd conjugation}

This conjugation contains verbs whose infinitive can have suffixes $-\bar{a}-,-\bar{e}-,-\bar{\imath}-,-o-$ and whose present stem is constructed by adding the present tense suffix to the infinitive stem -j-: 


Infinitive
domā-t
jautā- $t$
vērtē- $t$
slēpo- $t$
zeltī- $t$

Present Indefinite
domāaj-u
jautāj-u
vērtēj-u $u$
slēpoj-u
zeltīj-u

$$
\begin{aligned}
& \text { 'to think - I think' } \\
& \text { 'to ask - I ask' } \\
& \text { 'to assess - I assess' } \\
& \text { 'to ski - I ski' } \\
& \text { 'to gild - I gild' }
\end{aligned}
$$

The singular verb forms of the 2nd conjugation and both singular and plural 3rd person verb forms have lost their personal endings and the present suffix in Latvian as a result of the reduction of the final syllables (see Table 2.2).

\begin{tabular}{|c|c|c|}
\hline Infinitive & \multicolumn{2}{|c|}{ Present Indefinite } \\
\hline lasī-t & las-u & 'to read - I read' \\
\hline$m \bar{a} c \bar{\imath}-t$ & $m \bar{a} c-u$ & 'to teach - I teach' \\
\hline audzināa-t & audzin-u & 'to educate - I educate' \\
\hline$d z i e d \bar{a}-t$ & dzied-u & 'to sing - I sing' \\
\hline gulē-t & gul,-u & 'to sleep - I sleep’ \\
\hline
\end{tabular}

\section{3rd conjugation}

This conjugation contains verbs with the suffixes $-\bar{l}-,-i n \bar{a}-,-\bar{a}-,-\bar{e}-$, and the verbs whose present stem is built by reducing the stem of the infinitive, for example:

3rd conjugation verbs are divided into two groups depending on the suffix in the infinitive and the paradigm of the personal ending in the present (see Table 2.2):

The 3rd conjugation 1st group contains verbs with the following suffixes in their infinitive forms: -ì- and -inā- - lasit 'to read', rakstìt 'to write', mācities 'to learn', audzināt 'to educate', sasveicināties 'to greet', vingrināties 'to practice', and others.

The 3rd conjugation 2nd group contains verbs with the following suffixes in their infinitive forms: $-\bar{a}$ - un -ē- $-d z i e d \bar{a} t$ 'to sing', mìlèt 'to love', turēt 'to hold', gulēt 'to sleep', and others.

\subsection{Tense}

The category of tense in Latvian is based on a system of three tenses: the present, past, and future. Every tense has three indefinite and three perfect tense forms. Thus, the paradigm of the verb tense category is formed by six tense forms: the present indefinite, past indefinite, future indefinite, present perfect, past perfect, and future perfect (Ahero et al. 1959, 583-584; Paegle 2003, 97; Kalnača 2013b, 470). 
Table 2.2: Latvian indefinite and perfect tense forms (active voice) (adapted from Kalnača 2013b, 551-553)

celt 'to raise' (1st conjugation), domät 'to think' (2nd conjugation), lasit 'to read' (3rd conjugation, 1st group), dziedāt 'to sing' (3rd conjugation, 2nd group)

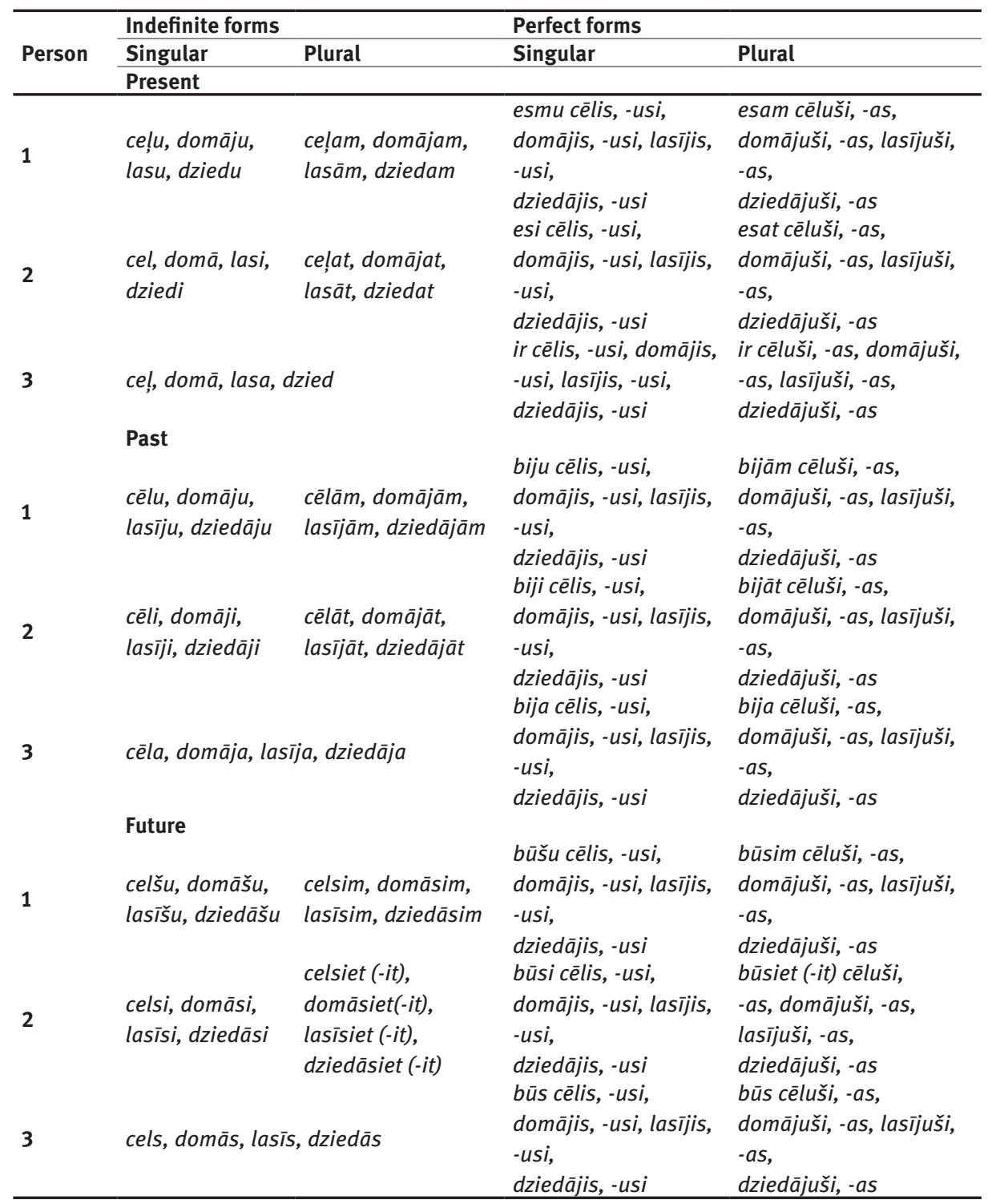


Latvian perfect tense forms are constructed from two components: finite forms in the present, past, or future tenses of the auxiliary verb būt 'to be' together with the past active participle (see Table 2.2):

$\begin{array}{llll}\text { (2.11) } & \text { Šodien Bille } & \text { ar } & \text { vecomāti } \\ \text { today Bille.NOM.F } & \text { with } & \text { grandmother.INS.F } \\ & \text { ir } & \text { gājušas } & \text { ilgi. } \\ \text { be.AUX.PRS.3 } & \text { go.PTCP.PST.F } & \text { long }\end{array}$

'Today Bille and her grandmother have been walking for a long time.'

(Belševica)

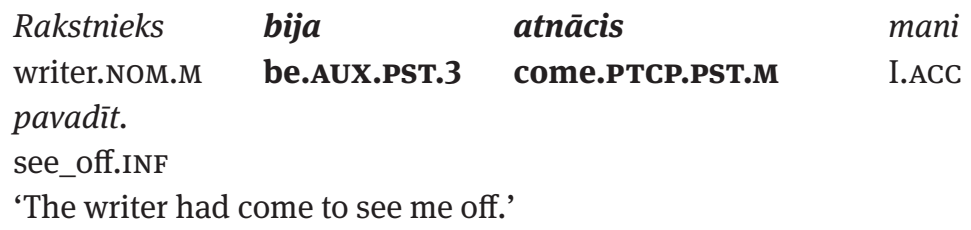

(Johansons)

\begin{tabular}{llll} 
Jaunība & būs & pagājusi, bet & kas \\
youth.NOM.F & be.AUX.FUT.3 & \multicolumn{1}{c}{ pass.PTCP.PST.F but } & what \\
padarits? & & \\
achieve.PST.M & & \\
'Youth will have passed, but what will have been achieved?'
\end{tabular}

(Priede)

The perfect tense participle is also marked for grammatical gender by showing agreement with the subject in the syntactic centre of the sentence; see examples (2.11).

Since the subject of the sentence in Latvian is mostly in the nominative, the finite participle in the active voice in its perfect tense form has only singular and plural nominative forms.

The present perfect singular and plural 3rd person forms in Latvian may omit the auxiliary verb ir 'has, have' or, in other words, we can see the so-called zero form of the auxiliary verb, for example:

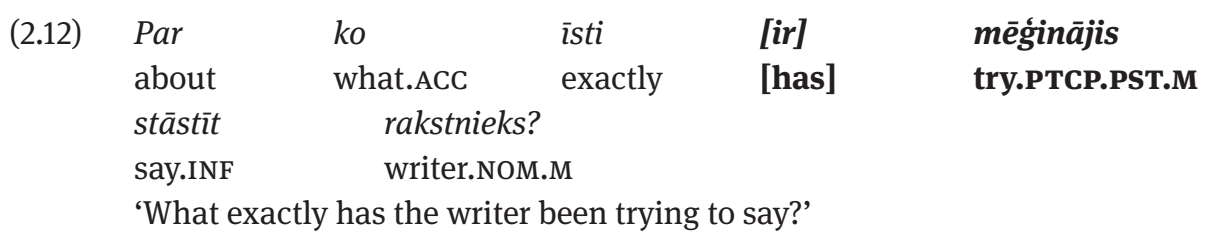


In other person or tense forms the zero form of the auxiliary verb can be seen less often as in, for example, the singular past perfect 3rd person form:

\begin{tabular}{|c|c|c|c|c|}
\hline Pie vārtiem Sveilis & $v \bar{e} l$ & atījās. & & \\
\hline Kā tad - arī & vinga & [bija] & skatijusies & pakal \\
\hline certainly - and & she.NOM & [had] & look.PTCP.PST.F & back \\
\hline
\end{tabular}

(Upīts)

Attitudes towards tense in the grammatical system can be best seen in the active voice indicative mood verb forms. In these there is a symmetrical set of three indefinite and three perfect tense forms in the present, past, and future, in addition to a varied contextual use of the tense forms (Paegle 2003, 97; Kalnača 2013b, 471). Therefore, the whole set of these forms can be considered as the centre of the functional system of the verb tense forms (Paulauskienè 1994, 326). The non-indicative mood (oblique, conditional, and debitive moods) tense forms, passive voice forms, and participle forms of the verb can be considered as peripheral. Expression of attitudes towards tense is not the main function of these verb tense forms, it is rather the expression of modality, voice, or the sequence of actions. For example, the tense meaning of the verb forms expressed in the oblique, debitive, or conditional moods usually match the contextual indicative mood forms, expressing simultaneity, predecession, or sequentiality with regard to them.

In the passive voice, just like the active voice, the indicative mood has six tense forms; the oblique and conditional moods are similar in both voices. The passive voice tense form meaning and use usually agree with the respective tense form in the active voice in the indicative mood. Since the main function of the passive voice form is to express actions where the agent is not important, the meaning of the tense can also be considered as peripheral for these forms, too.

\subsection{Person}

The person category of the Latvian verb contains three persons in the singular and three persons in the plural (see Table 2.2).

There are three kinds of means to express the person in Latvian (Paegle 2003, 92-93, see also Siewierska 2004; Cysouw 2008 from the point of view of grammar typology):

1. personal endings for synthetic verb forms;

2. auxiliary verbs in the finite form for analytic verb forms;

3. personal pronouns, nouns, or words used in the function of the noun, if the verb does not have a personal ending. 
The indefinite tense forms in the indicative mood are usually expressed with the help of a non-reflexive or reflexive ending, for example, Tables 2.3, 2.4:

Table 2.3: The paradigm of personal forms, indicative mood for lasitt 'to read', smieties 'to laugh' (adapted from Kalnača 2013a, 75-77)

\begin{tabular}{lll}
\hline Person & Singular & Plural \\
\hline 1 & las-u, smej-os & las-ām, smej-amies \\
2 & las-i, smej-ies & las-āt, smej-aties \\
3 & las-a, smej-as & \\
\hline
\end{tabular}

In a similar way the person is expressed with the help of a reflexive or non-reflexive ending in the imperative mood (except for the non-existent 1st person singular form), for example:

Table 2.4: The paradigm of personal forms, imperative mood for lasit 'to read', smieties 'to laugh' (adapted from Kalnača 2013a, 75-77)

\begin{tabular}{lll}
\hline Person & Singular & Plural \\
\hline 1 & - & lasīs-im!, smies-imies! \\
2 & las-i!, smej-ies! & las-iet!, smej-ieties! \\
3 & lai las-a!, lai smej-as! & \\
\hline
\end{tabular}

There is a common feature in both Latvian and Lithuanian which makes these languages different from other Indo-European languages. Namely, the 3rd person form is unmarked and identical in singular and plural in both non-reflexive and reflexive verbs (see Tables 2.2-2.4).

Historically, the 3rd person verb does not have an ending and the form ends in an athematic vowel or is reduced to a zero morpheme. Neither in dialects nor in old texts can there be found traces of a 3rd person ending in singular or plural (Endzelinn 1981, 478-480). The causes for this peculiarity still remain unclear.

All the analytic verb forms have a morphologically expressed 3rd person singular and plural feature (together with gender characteristics), signaled by the finite present and past participle form, as in, for example, the perfect tenses in the indicative mood (see Table 2.2).

Depending on the function of person, all Latvian moods can be divided into two groups: 
1. moods where verbs have morphologically expressed personal forms: the indicative and imperative moods;

2. moods where verbs do not have morphologically expressed personal forms: the oblique, conditional, and debitive moods.

This distinction is based on the semantics and functions of the moods in the language system. The indicative mood is the most important, as it ensures the process of communication in its main form: the dialogue, which demands a specific grammar form set in three persons in the singular and plural. The essence of the imperative mood is to use a direct or indirect order, request, or suggestion to make the addressee of the utterance accomplish some kind of an action, which dictates the necessity for the morphological form of the person. The absence of personal endings in the oblique, conditional, and debitive moods necessitates the expression of the person contextually with the help of a personal pronoun, noun, or word used in the function of a noun (see Table 4.1, Chapter 4).

The synthetic forms of the Latvian verb have two main types of personal endings:

1. non-reflexive endings;

2. reflexive endings.

Although historically Latvian and, in general Baltic, personal endings have not been connected with tense forms (Rudzite 1960, 177-181), the partial or full reduction of the final syllable and the fusion of the verb ending in Latvian have caused the development of independent personal ending paradigms in different tense forms with variants in the present tense.

It is possible to propose the following system of person and number endings of a verb in Tables 2.5-2.6 (non-reflexive verbs) and Tables 2.7-2.8 (reflexive verbs) (endings preceded by palatalisation have been displayed as separate exponents).

Tables 2.5-2.8 contain personal endings in all conjugations, except for the irregular verbs būt 'to be', iet 'to go', dot 'to give', which have preserved partially athematic and therefore irregular personal forms in the modern language system. The markers are as follows:

1 - 1st conjugation, divided in two groups:

$1 \mathrm{a}$ - all 1st conjugation verbs, excluding $1 \mathrm{~b}$ - verbs whose 2nd person singular ending

is $-i$, singular and plural in the common form $-\varnothing$,

2 - 2nd conjugation

3 - 3rd conjugation, divided into two groups:

$3 \mathrm{a}$ - verbs whose personal endings are $-u,-i,-a$ (SG), $-\bar{a} m(i e s),-\bar{a} t(i e s),-a(\mathrm{PL}), 3 \mathrm{~b}-$ all other 3rd conjugation verbs.

In the Latvian literary language, 2nd person future indefinite plural forms can have two kinds of endings -it un -iet (for reflexive verbs these are: -ities and -ieties). Historically, 
the more ancient ending common with Lithuanian is -it (resp. -ities) and it has had a parallel version in Latvian since the 17th century -iet (resp. -ieties). Out of respect for the more ancient form, the literary language accepts both versions (see for example, Veidemane 2002, 414-415; Paegle 2003, 93; Kalnača 2013b, 520). Ozola (2005) points out that in the second half of the 20th century, school grammars were promoting the use of the forms -iet, -ieties, therefore in modern day speech these are more frequent. The personal ending paradigm discussed below does not distinguish -it/-iet or -ities/ieties as separate exponents.

Tables 2.5-2.8 do not reflect the syncretism of 3rd person SG/PL; however, in the later analysis this has been taken into account.

\section{Non-reflexive}

Table 2.5: The personal endings of the singular non-reflexive paradigm

SG

\begin{tabular}{|c|c|c|c|c|c|c|c|c|}
\hline \multirow{3}{*}{ Person } & Prese & & & & & Past & Future & \multirow{3}{*}{$\begin{array}{l}\text { Number of } \\
\text { exponents }\end{array}$} \\
\hline & \multicolumn{7}{|c|}{ Conjugation } & \\
\hline & 2 & $1 a$ & $3 b$ & 1b & $3 a$ & all & all & \\
\hline 1 & $-u$ & $-{ }^{\circ} u,-u$ & & $-u$ & & & & 2 \\
\hline 2 & \multirow{2}{*}{$-\varnothing-\varnothing$} & $-\varnothing$ & $-i$ & & & & & 3 \\
\hline 3 & & $-‘ \varnothing,-\varnothing$ & & $-\varnothing$ & $-a$ & & $-\varnothing$ & 4 \\
\hline
\end{tabular}

Table 2.6: The personal endings of the plural non-reflexive paradigm

$\mathrm{PL}$

\begin{tabular}{|c|c|c|c|c|c|c|}
\hline \multirow{3}{*}{ Person } & \multicolumn{3}{|c|}{ Present } & Past & Future & \multirow{3}{*}{ Number of exponents } \\
\hline & \multicolumn{5}{|c|}{ Conjugation } & \\
\hline & 2 & $1,3 b$ & $3 a$ & all & all & \\
\hline 1 & $-a m$ & $\begin{array}{l}-' a m, \\
-a m\end{array}$ & $-\bar{a} m$ & & $-i m$ & 4 \\
\hline 2 & $-a t$ & $\begin{array}{l}-' a t, \\
-a t\end{array}$ & $-\bar{a} t$ & & $\begin{array}{l}-i t / \\
-i e t\end{array}$ & 4 \\
\hline 3 & $-\varnothing-\varnothing$ & $-\varnothing \varnothing,-\varnothing$ & $-a$ & & $-\varnothing$ & 4 \\
\hline
\end{tabular}

The Latvian non-reflexive verb personal endings point not only to the abovementioned 3rd person SG/PL syncretism, but also to the syncretism of the singular 2nd and 3rd person in 1a and the 2nd conjugation verbs in the present tense. In addition, 2nd conjugation verbs in their present tense 2 nd and 3rd person forms have zero morphs 
not only in their endings but also in the present tense suffix -j-. This results in the 1SG, 1PL, 2PL forms domāju 'I think', domājam 'we think', domājat 'you think', and the 2SG, 3SG/PL syncretic form domā 'he/she thinks, they think'. Reflexive verbs have not only a syncretic SG/PL 3rd person in all tenses, but also in their future tense 2SG un 3SG/PL forms ending in -ies.

\section{Reflexive}

Table 2.7: The personal endings of the singular reflexive paradigm

SG

\begin{tabular}{|c|c|c|c|c|c|}
\hline \multirow{3}{*}{ Person } & Present & & Pas & & \multirow{3}{*}{ Number of exponents } \\
\hline & \multicolumn{4}{|c|}{ Conjugation } & \\
\hline & 1,2 & 3 & all & all & \\
\hline 1 & -'os, -os & - os & & & 2 \\
\hline 2 & -ies & & & & 1 \\
\hline 3 & -as, -as & $-\bar{a} s$ & & & 4 \\
\hline
\end{tabular}

Table 2.8: The personal endings of the plural reflexive paradigm

$\mathrm{PL}$

\begin{tabular}{|c|c|c|c|c|}
\hline \multirow{3}{*}{ Person } & Present & Past & Future & \multirow{3}{*}{$\begin{array}{l}\text { Number of } \\
\text { exponents }\end{array}$} \\
\hline & \multicolumn{3}{|l|}{ Conjugation } & \\
\hline & $1,2,3 b$ & all & all & \\
\hline 1 & -'amies, -amies & -āmies & -imies & 4 \\
\hline 2 & -'aties, -aties & -āties & -ities // -ieties & 4 \\
\hline 3 & -'as, -as & $-\bar{a} s$ & -ies & 4 \\
\hline
\end{tabular}

In regard to the personal forms of the verb, it is interesting to examine the idea proposed by Haspelmath $(2002,241)$ that "frequent categories are more differentiated than rare categories”. As pointed out by Haspelmath, inflectional languages generally display the following grammatical form frequency (2002, 238), for number: singular $>$ plural > dual, for person: 3rd > non-3rd (1st/2nd), for tense: present > future. Thus, the respective verb personal ending exponents should be arranged in the following way: the most frequent use in the present tense singular 3rd person. In Latvian, this suggestion is validated with regard to present tense non-reflexive and reflexive verbs. As can be seen in Tables 2.5-2.6, there is more variety in the personal endings in connection with the conjugations than in the present or the past. In the situations where the personal form paradigms are the same for all verbs and where there is no difference between the conjugations. 
However, the principles relating to the frequency of person and number categories in Latvian cannot be validated. That is, the 3rd person verb, as the most frequently used form in Latvian, should have also had the most exponents. Taking into account the 3rd person SG/PL syncretism in Latvian, the number of both non-reflexive and reflexive exponents is the smallest. There are only four exponents for each verb group, as morphologically they are the same in both singular and plural. However, non-reflexive verbs have five exponents in the 1st person SG+PL and seven exponents in the 2nd person SG+PL, while reflexive verbs have six exponents in the 1st person $\mathrm{SG}+\mathrm{PL}$ and five exponents in the 2nd person SG+PL. According to the number of exponents, the most frequently used verb forms would be those of the 2nd person, which have a total of twelve exponents in Latvian, and those of the 1st person, which have a total of eleven exponents. This is opposed to the eight exponents of the 3rd person. This, of course, does not agree with the frequency of use of the particular personal forms in the language. Therefore, we can consider that due to the syncretism of the 3rd person SG/PL, the asymmetry between the 3rd and non-3rd person (1st/2nd) usage and their respective number of the exponents are features that have already been "programmed" into the Latvian verb system.

In the same way, Latvian does not validate the frequency difference principle, which suggests that there should be more personal ending exponents in the singular, since the singular forms are used more frequntly. However, in the analysis of the exponents, we should take into account that the 3rd person cannot be included in the analysis, as it does not have a morphological distinction for the singular and plural, and therefore we can examine only the cases of the 1st and 2nd person. Latvian has a particular bias for the exponents in the plural as both non-reflexive and reflexive verbs have eight exponents each (1st + 2nd PL). In the singular (1st + 2nd SG), however, nonreflexive verbs have five exponents, while reflexive verbs have only three. This case, however, does not support the prediction that the singular is used less frequently than the plural and that the 1st and 2nd person plural forms in Latvian are used more frequently than the 1st and 2nd person singular forms. The most plausible cause for this kind of asymmetry of frequency and number of exponents would be historical changes taking place during the development process of the verb endings as a result of the syncretism of the personal and number forms. 